\title{
Bovine fetal tissue extracts as an alternative to fetal serum for in vitro reproduction of viruses
}

\author{
Rustam Y. Gilmutdinov ${ }^{1}$, Albert K. Galiullin ${ }^{1, *}$, Gennady N. Spiridonov ${ }^{2}$, and Pavel V. Sovronov ${ }^{1}$ \\ ${ }^{1}$ Kazan State Academy of Veterinary Medicine named after N.E. Bauman, Kazan 420029, Russia \\ ${ }^{2}$ Federal center for toxicological, radiation and biological safety, Scientific town-2, Kazan city 420075, Russia
}

\begin{abstract}
The authors assessed the possibility of substitution of the serum component with tissue extracts (muscles, liver, kidneys) of bovine fetuses in the culture medium during the cultivation of transplanted LEK and Vero cell lines, as well as the reproduction of infectious rhinotracheitis IR, PI-3 viruses and reovirus on them. The greatest stimulating effect on LEK and Vero cells was obtained from bovine fetuses muscle extract. The effect of this extract on the proliferative activity of LEK and Vero cells is significant and amounts to 27 and 25\%, respectively. The power of the effect of liver and kidney extracts is significantly lower and equal, respectively, 15 and 18\% for LEK and 14 and 19\% for Vero, although it is reliable. The reproductive activity of IR and PI-3 viruses when using tissue extracts was inferior to that when using blood serum. The stimulating effect of blood serum and muscle extract on the reproduction of reovirus was comparable. The effect of fetal muscle extract on the reproduction of IR, PI-3 viruses and reovirus is reliable and amounts to 29,31 and 33\%, respectively. In general, it is close to that of the blood serum of bovine fetuses - 30, 35 and 36\%. The power of the influence of the liver and kidney extracts of the bovine fetuses is significantly lower and comparable to that of the blood serum of the cows themselves: 25, 23 and 20\%, although it is reliable.
\end{abstract}

\section{Introduction}

Today the most important component of the nutrient medium for the production of somatic eukaryotic cells is the blood serum of animals. For a long time, it remained an indispensable component for the growth media of most cell cultures. It remains an irreplaceable component of the growth medium for most cell cultures [1].

However, the use of animal blood serum has a number of significant limitations. It is quite expensive, especially if it is obtained from animal fenses. When cells are produced for the purpose of viral reproduction, blood serum can inhibit this process due to the possible presence of antibodies to the virus being produced and increase the risk of contamination, for example, with other viruses.

Traditionally, fetal blood serum is used as a growth additive for cell production, which is a complex mixture of high- and low-molecular biomolecules with a physiological balance of stimulating and blocking components, as well as with a low content of antibodies - $\gamma$-globulins - inhibitors of cell growth and proliferation [2,3].

However, this serum component is far from ideal. It is a source of xenogenic proteins during cell cultivation and is currently not recommended due to the possibility of allergic reactions to cellular preparations intended for human administration, as well as the transfer of viruses, prions and pathogens of zoonotic infections into human body $[4,5]$.

Moreover, it is known that the composition of fetal blood serum varies significantly in the content of active components, which makes it impossible to standardize it for the most significant components [6]. This often creates technical, economic and scientific difficulties in the selection of fetal blood serum for certain cell lines, and in some cases - when comparing the results using different fetal blood sera even in one

* Corresponding author: albert-954@mail.ru 
laboratory, as well as similar results obtained in different laboratories.

At the same time, the selection of fetal blood serum for a particular culture is a time-consuming and labor-intensive process. In addition, the limitedness of each batch of fetal serum determines the need for full retesting.

The main disadvantages of fetal blood serum as a growth supplement for the production of cells intended for human administration are as follows:

- fetal blood serum is a xenogenic (in relation to humans) material;

- the possibility of transferring infectious agents from the blood serum of fetuses, including mycoplasma, zoonoses, prions and viruses (including bovine diarrhea virus, parvoviruses causing bovine encephalopathy, as well as unidentified viruses);

- the possibility of transferring free xenogenic DNA from ETS;

- the possibility of transferring unwanted metabolites from ETS;

- the possibility of an immunological response to ETS, including allergic reactions to xenogenic components;

- the change in the expression of a number of markers in human cells produced in the presence of fetal blood serum;

- the non-standardization of fetal blood serum in terms of functional activity.

The ban on the use of fetal blood serum in the production of cell products is regulated in Western Europe [7] and in Russia [8].Many attempts were made to replace the serum component with hydrolysates of animal and plant origin [9-11, etc.].

The extracts of various tissues, biological fluids and versions of serum-free media were tested, but satisfactory results were not obtained [12].

In this aspect, animal tissue extracts have a significant potential, which is still poorly realized. Particularly promising are tissue extracts of bovine fenses which allow reducing the concentration of blood serum and achieving the balance of chemical components of the culture medium up to substitution [13].

In the early stages of the formation of cell cultures, they were widely used, but later they actually ceased to be used. The assessment of the biological properties and biochemical composition of extracts from muscles, liver, kidneys of bovine fenses was given [14, etc.].

It is possible to assume that tissue extracts of bovine fenses are an effective bioadditive to media for cell production, in particular for the purpose of reproducing viruses and obtaining vaccine and diagnostic preparations against pathogens of agricultural animals.

The substitution effect can be assessed for a number of items, the main of which are the reduction of the medium cost; the increase in the proliferative activity of cells in which the virus is produced; increasing the reproductive activity of the viruses themselves. The first point is obvious, and has no direct relation to biology, therefore, in this paper we considered only the last two conditions.

\section{Materials and methods}

The research was carried out in Kazan State Academy of Kazan State Academy of Veterinary Medicine named after N.E. Bauman and Federal center for toxicological, radiation and biological safety. To replace the blood serum of cows and their fetuses, the extracts of muscles of the hind limbs and organs (liver, kidneys) of 20 fetuses weighing 5-10 kg from clinically healthy cows were used. The listed tissue components were ground in a meat grinder, poured with Hanks solution in a ratio of 1:5 by weight and extraction was carried out at $2^{\circ} \mathrm{C}$ for 24 hours with constant stirring. Then, after preliminary filtration, tissue materials were sterilized through membrane filters FMAC-0.2 and FMPA-0.2 (Vladisart, Russia).

The viruses were the causative agents of infectious rhinotracheitis (IR) and parainfluenza-3 (PI-3), as well as reovirus type 1 , «Lang» strain.

Viruses PI-3 and IR were propagated in the monolayer of the transplanted line of the lung cells of bovine fetus - "LEK"; and reovirus - on the transplanted cell line of the kidney of the African green monkey «Vero» [15]. LEK and Vero cells are used for vaccine production. They are characterized by a well-defined genetic background and a stable karyotype.

The cells were produced under standard conditions in a thermostat at $37^{\circ} \mathrm{C}$ in $200 \mathrm{ml}$ glass mattresses. Growthstimulating components were added at $10 \%$ concentration to the Igla-MEM culture medium. In addition, antibiotics (kanamycin sulfate, streptomycin sulfate, and benzylpenicillin) were introduced into the media at $100 \mathrm{U} / \mathrm{ml}$.

The proliferative activity of LEK and Vero cell cultures was studied after 72 hours of incubation. The monolayer is formed by epithelial-like LEK cells for 3-4 days on Igla-MEM medium.

The cells were removed from glass with trypsinversene solution (1: 3) and counted in a Goryaev chamber. The proliferation index, as an indicator of the effectiveness of growth-stimulating components, was assessed by the generally accepted method according to the work [16].

The reproduction of viruses was determined by their cytopathic effect (CPE) in the monolayer of the transplanted cell line and was assessed by the titer expressed in tissue cytopathic dose lg TCID50 / $\mathrm{ml}$. The infectious titer of PI-3 and IR viruses reaches LEK105106TCD50 / ml. The serum research was based on the 
detection of antibodies to the studied viruses using the hemagglutination reaction (HR).

The obtained experimental data was processed by the methods of variation statistics [17], which included the calculation of the arithmetic mean value, the error of the arithmetic mean, the criterion for the reliability of the difference and the power of influence. The power of the influence of various factors was studied by the method of analysis of variance using the STATAN-96 software package for a personal computer. The analysis of variance allows identifying dependencies in experimental data by examining the significance of differences in mean values. Unlike the t-test, it allows comparing the mean values of three or more groups. The analysis of variance is about studying the effect of one or more independent variables (usually called factors) on the dependent variable.

\section{QRResults}

The research results presented in Table 1 indicates a high proliferative activity of LEK and Vero cell cultures after $72 \mathrm{~h}$ of incubation in a medium with various extracts.

The minimum growth-stimulating activity was in the extract of the liver of cows out of the 3 tissue preparations. The greatest proliferation was provided by muscle extract, although it was inferior in this bovine serum. Despite the low content of total protein in tissue extracts of cow fruits in comparison with bovine blood serum of [18], about $50 \%$ of it in the reserach extracts is represented by albumin, while in serum their share does not exceed 29\%. Namely, the latter are usually associated with the growth-stimulating activity of animal blood serums.

The analysis of variance carried out in cell cultures for all considered factors confirmed the inconsistency of the null hypothesis of a random difference in the indicators of growth-stimulating factors.

The contribution of each of the considered factors to the proliferative activity of cells was significant and amounted, respectively, $15-27 \%$ for LEK and $14-25 \%$ for Vero (Table 2).
Table 1. Proliferation index of LEK and Vero cell cultures

\begin{tabular}{|l|l|l|}
\hline $\begin{array}{l}\text { Growth- } \\
\text { stimulating } \\
\text { component of } \\
\text { culture medium }\end{array}$ & LEK & Verl culture \\
\cline { 2 - 3 } Tissue extracts of: & \multicolumn{2}{|l|}{} \\
\hline muscles & $4.5 \pm 0.07 *$ & $4.2 \pm 0.09 *$ \\
\hline liver & $2.5 \pm 0.11 * * *$ & $2.5 \pm 0.07 * * *$ \\
\hline kidneys bovine & $3.4 \pm 0.07 * * *$ & $3.4 \pm 0.06 * * *$ \\
\hline $\begin{array}{l}\text { Control - } \\
\text { blood serum }\end{array}$ & $5.6 \pm 0.19$ & $5.2 \pm 0.22$ \\
\hline
\end{tabular}

Note: $* * *, * * *$ - levels of significance of differences relative to control (p), respectively $<0.05 ;<0.01$ and $<0.001$.

Table 2. Influence power of the type of growth-stimulating component on the proliferative activity of LEK and Vero cells

\begin{tabular}{|c|c|c|c|c|c|}
\hline $\begin{array}{c}\text { Cell } \\
\text { culture }\end{array}$ & Factors & $\begin{array}{c}\text { Influence } \\
\text { power, } \\
\% \\
\end{array}$ & $\begin{array}{l}\text { f- Fisher's } \\
\text { criterion }\end{array}$ & $\begin{array}{c}\text { Degree } \\
\text { of } \\
\text { freedom } \\
\text { k1 } \\
\end{array}$ & $\begin{array}{c}\text { Degree } \\
\text { of } \\
\text { freedom } \\
\text { k2 } \\
\end{array}$ \\
\hline LEK & \multicolumn{5}{|c|}{ Tissue extracts } \\
\hline & muscles & 27 & 10 & 4 & 50 \\
\hline & liver & 15 & 25 & 8 & 110 \\
\hline & kidneys & 18 & 9.9 & 7 & 42 \\
\hline & $\begin{array}{l}\text { Control - bovine } \\
\text { blood serum }\end{array}$ & 32 & 7.3 & 3 & 11 \\
\hline Vero & \multicolumn{5}{|c|}{ Tissue extracts } \\
\hline & muscles & 25 & 15 & 9 & 90 \\
\hline & liver & 14 & 13 & 6 & 183 \\
\hline & kidneys & 19 & 6.8 & 2 & 53 \\
\hline & $\begin{array}{l}\text { Control - bovine } \\
\text { blood serum }\end{array}$ & 35 & 11.5 & 3 & 23 \\
\hline
\end{tabular}

The use of one-way analysis of variance allowed identifying a complex of tissue 
extracts, on which the proliferative activity of cells depends. It was shown that the effect of muscle extract on the formation of an indicator of cell proliferative activity was significant and amounted to $27 \%$ for LEK and 25\% for Vero; the power of the effect of the tissue extract of liver and kidneys was significantly lower and equal, respectively, 15 and 18\% for LEK, 14 and $19 \%$ for Vero.

It was found that for both LEK cells and Vero cells, the main tissue extracts that determined statistically significant differences in cell proliferative activity were, in decreasing order of magnitude, extracts of muscles, liver, and kidneys. Moreover, they were significantly inferior to bovine blood serum.

The IR virus provided CPE on the monolayer of the transplanted LEK cell line in 48-96 hours after infection. The first signs of the presence of CPE were granularity, rounding of cells, their arrangement in the form of clusters with thinned bridges and clusters at the ends. The process starts at the edges and extends to the entire monolayer. As a rule, with a small dose of the virus spherical synthesia are formedcontaining 10-20 nuclei.

Table 3. Titers of IR and PI-3 viruses during reproduction of LEK cell culture

\begin{tabular}{|c|c|c|}
\hline \multirow[t]{2}{*}{$\begin{array}{c}\text { Growth-stimulating component of culture } \\
\text { medium }\end{array}$} & \multicolumn{2}{|c|}{$\begin{array}{c}\text { Virus titre, lg Tissue cytopathic } \\
\text { dose } 50 / \mathrm{ml}\end{array}$} \\
\hline & IR & PI-3 \\
\hline \multicolumn{3}{|l|}{ Tissue extracts of: } \\
\hline muscles & $6.2 \pm 0.1 *$ & $4.7 \pm 0.2^{*}$ \\
\hline liver & $4.7 \pm 0.2 * *$ & $4.0 \pm 0.2 * * *$ \\
\hline kidneys & $4.7 \pm 0.3 * *$ & $4.2 \pm 0.1 * * *$ \\
\hline Fetal bovine blood serum & $7.0 \pm 0.2$ & $7.0 \pm 0.2$ \\
\hline Control - bovine blood serum & $6.7 \pm 0.1$ & $6.5 \pm 0.3$ \\
\hline
\end{tabular}

Note: $*, * *, * * *$ - the levels of significance of differences relative to control (p), respectively $<0.05 ;<0.01$ and $<0.01$.

The PI-3 virus is characterized by the presence of either granular and vacuolated rounded cells in the infected monolayer, or multinucleated symplasts, due to cell fusion. At the same time, they lose the ability to mitosis, die and outwardly this is manifested by their falling away from the glass. As a result, "windows" are formed in the monolayer.

The intensity of reproduction of IR and PI-3 viruses in LEK cell culture is shown in Table 3.

According to table 3, the largest amount of viral mass of IR and PI-3 was obtained using medium bovine blood serum in the culture $(6.7+0.1$ for IR and $6.5+0.3$ for PI-3), as well as their fruits (7.0 + 0.2 for IR and PI-3).

The muscle extract turned out to be the best out of non-serum components $(6.2+0.1$ for IR and $4.7+0.2$ for PI-3) and showed the best growth-stimulating effect for IR. Its titer was only $7 \%$ lower than the control, whereas when the IR virus was passaged on LEK in a culture medium using extracts of bovine liver and kidneys, the reproduction was lower than in the control by $30 \%$, and the PI-3 virus was lower by 39 and $35 \%$, respectively.

In reovirus, due to the longer reproduction period, the early manifestation of CPE is problematic. It is manifested by the formation of rounded granular cells and the monolayer as a whole resembles a nonspecific degeneration, which causes certain difficulties in identification. The cells affected by reovirus do not slough off the glass, attach to it by processes and become granular. There are features of CPE during the use of growth-stimulating component of the liver of fetal cows: large rounded plaques are formed in the monolayer and connected by bridges. The dependence of the intensity of reproduction of reovirus in the culture of Vero cells on the type of growth-stimulating component is shown in Table 4. 4.

Table 4. Titers of reovirus during reproduction on Vero cell culture

\begin{tabular}{|c|c|}
\hline $\begin{array}{c}\text { Growth-stimulating component } \\
\text { of culture medium }\end{array}$ & $\begin{array}{c}\text { Virus titer in } \\
\text { RHA, } \mathbf{~ / ~} \mathbf{~}\end{array}$ \\
\hline Extracts of & 64 \\
\hline muscles & 32 \\
\hline liver & 32 \\
\hline kidneys & 64 \\
\hline Fetal bovine blood serum & 32 \\
\hline
\end{tabular}

According to Table 4, the reproduction of reovirus during the use of muscle extract in the culture medium is comparable with the use of blood serum from fetal cows (titer in RHA 1:64) and higher than during the use of extracts of kidneys, liver and even with bovine blood serum (titer in RHA $1: 32$ ).

The use of univariate analysis of variance allowed determining the degree of influence of individual tissue extracts of fetuses on the reproduction of viruses IR, PI-3 and reovirus (Table 5). 
Table 5. Influence power of the type of growth-stimulating component on the proliferative activity of IR, PI-3 and Vero cells

\begin{tabular}{|c|c|c|c|c|c|}
\hline Cell culture & Factors & $\begin{array}{c}\text { Influence } \\
\text { power, } \\
\%\end{array}$ & $\begin{array}{c}\text { f- } \\
\text { Fisher's } \\
\text { criterion }\end{array}$ & $\begin{array}{c}\text { Degree } \\
\text { of } \\
\text { freedom } \\
\text { k1 }\end{array}$ & $\begin{array}{c}\text { Degree } \\
\text { of } \\
\text { freedom } \\
\text { k2 }\end{array}$ \\
\hline IR & \multicolumn{5}{|l|}{ Tissue extracts: } \\
\hline & muscles & 29 & 11 & 3 & 17 \\
\hline & liver & 27 & 4.5 & 2 & 23 \\
\hline & kidneys & 23 & 21 & 5 & 175 \\
\hline & Fetal bovine blood serum & 30 & 2.6 & 7 & 119 \\
\hline & Control - bovine blood serum & 25 & 5 & 10 & 85 \\
\hline \multirow[t]{6}{*}{ PI-3 } & \multicolumn{5}{|l|}{ Tissue extracts: } \\
\hline & muscles & 31 & 7 & 5 & 23 \\
\hline & liver & 21 & 12 & 1 & 13 \\
\hline & kidneys & 22 & 23 & 7 & 185 \\
\hline & Fetal bovine blood serum & 35 & 3.7 & 11 & 78 \\
\hline & Control - bovine blood serum & 23 & 9 & 15 & 110 \\
\hline Reovirus & \multicolumn{5}{|l|}{ Tissue extracts: } \\
\hline & muscles & 33 & 9.2 & 8 & 13 \\
\hline & liver & 19 & 7.9 & 3 & 33 \\
\hline & kidneys & 15 & 13 & 6 & 58 \\
\hline & Fetal bovine blood serum & 36 & 2.7 & 7 & 92 \\
\hline & $\begin{array}{l}\text { Control - bovine blood } \\
\text { serum }\end{array}$ & 20 & 8 & 9 & 30 \\
\hline
\end{tabular}

Thus, the power of the effect of muscle extract on the reproduction of viruses IR, PI-3 and reovirus is reliable and amounts to 29, 31 and 33\%, respectively. In general, it is close to that of fetal bovine blood serum of $-30,35$ and $36 \%$. The power of the influence of the liver and kidney extracts of bovine fetuses is significantly lower and comparable to that of bovine blood serum themselves: 25, 23 and 20\%.

For the liver extract of bovine fetuses, it is reliable and amounts to $27 \%$ for IR, $21 \%$ for PI-3 and $19 \%$ for reovirus. For the extract of kidney of bovine fetuses, it is reliable and amounts to $23 \%$ for IR, $22 \%$ for PI-3 and $15 \%$ for reovirus.

It turned out that for all studied viruses (IR, PI-3 and reovirus), significant stimulating factors that determine statistically the differences in their reproduction are, in decreasing order, blood bovine fetal serum, muscle extract, bovine blood serum, liver extracts, kidneys.

\section{प्Conclusion}

The most promising substitute for serum component in the cultivation of LEK and Vero transplantable cell lines is the extract of the muscles of bovine fenses.

There is a slight decrease in the reproductive activity of IR and PI-3 viruses in culture media with extracts of tissues of bovine fenses, which is less pronounced in the case of muscle extracts.

For the reproduction of reovirus, the muscle extract of bovine fenses can be used as a substitute in the culture medium for bovine fetal blood serum (titer in RHA $1: 64)$.

The extracts of kidneys and liver are comparable to bovine blood serum in terms of the stimulating effect on the reproduction of reovirus.

\section{References}

1. B.I. Antonov, V.V. Borisova, P.M. Volkova et al., Laboratory research in veterinary medicine. Bacterial infections: collection (Agropromizdat, Moscow, 1986) $352 \mathrm{p}$.

2. R.Ya. Gilmutdinov, R.R. Zakirov, E.Yu. Khamzina, N.I. Guryanov, Biochemical composition and growth-stimulating effect on transplanted cell cultures of extracts from muscles, liver and kidneys of cow fetuses, Veterinarian, 4, 13-15 (2009)

3. V.I. Eremets, A.Ya. Samuilenko, N.K. Eremets et al., Improvement and standardization of technological processes, methods of control and quality management of antiviral vaccines, Veterinarian, 3, 4-7 (2011)

4. Catalog of a specialized collection of transplanted somatic cell cultures of agricultural and game animals, pp. 11-22 (Moscow, 2006)

5. N.A. Mazurkova, G.P. Troshkova, L.N. Shishkina et al., Creation of a nutrient medium based on soybean hydrolyzate obtained using bromelain for MDCK and Vero cells and evaluation of the growth properties of influenza virus vaccine strains in them, J. of Microbiology and Immunobiology (in Russian), 1, 86-90 (2011)

6. A.Ya. Samuylenko, The use of cell culture in the diagnosis of viral diseases, Infectious pathology of 
animals, diagnosis of viral infections, 7, 17-119 (2011)

7. I.S. Trukhan, Nutrient medium as a key factor in the cultivation of mammalian cells, Int. J. Appl. and Fund. Research, 12 (Part 1), 165-172 (2018)

8. Federal Law No. 180 of June 23, 2016 "On biomedical cell products"

9. N. Azouna, Phenotypical and functional characteristics of mesenchymal stem cells from bone marrow: comparison of culture using different media supplemented with human platelet lysate or fetal bovine serum, Stem Cell Res. / Then., 3(1), 6 (2012)

10. K. Bieback, Platelet Lysate as Replacement for Fetal Bovine Serum in Mesenchymal Stromal Cell Cultures, Transfus. Med. Hemother., 40(5), 326-335 (2013)

11. Guidance of Minimizing the Risk of Transmitting Animal Spongiform Encephalopathy Agents via Human and Veterinary Medical Products (EMA / 410/01).
12. Y.C. Kuo, S.S. Wang, Effect of bovine pituitary extract on the formation of neocartilage in chitosan / gelatin scaffolds, J. of the Taiwan Institute of Chemical Engineers, 40, 150-156 (2010)

13. M. Mojica-Henshaw, Serum-converted platelet lysate can substitute for fetal bovine serum in human mesenchymal stromal cell cultures, Cytotherapy, 15(12), 1458-1468 (2013)

14. B. Naaijkens et al., Human platelet lysate as a fetal bovine serum substitute improves human adiposederived stromal cell culture for future cardiac repair applications, Cell Tissue Res., 348(1), 119130 (2012)

15. P.A. Warnke, A. Humpe, D. Strunk et al., Clinically-feasible protocol for using human platelet lysate and mesenchymal stem cells in regenerative therapies, J. Craniomaxillofac Surg., 41, 153-161 (2013)

16. L. Wosu, Optimal parameters for in vitro growth of parvoviruses, Comp. Immunol. Microbiol. Infect. Dis., 10(1), 25-32 (1987) 